\title{
Urgensi Pembentukan Komite Etik Dan Hukum Rumah Sakit Dalam Penyelesaian Sengketa Medik Secara Non Litigasi
}

\author{
Hardini Indarwati, Djoko Widyarto JS. dan Valentinus Suroto \\ hardini_indarwati@gmail.com \\ Magister Hukum Kesehatan \\ Universitas Katolik Soegijapranata Semarang
}

\begin{abstract}
ABSTRAK
Penelitian ini bertujuan untuk mengetahui upaya/cara penyelesaian sengketa medis di RSUD Jombang, dan urgensi dibentuknya Komite Etik dan Hukum Rumah Sakit dalam rangka penyelesaian sengketa medis secara non litigasi.

Penelitian ini menggunakan metode kualitatif dengan pendekatan yuridis sosiologis. Aspek sosiologis terutama digunakan dalam menganalisis faktor-faktor yang mendorong perlu segera dibentuknya Komite Etik dan Hukum di Rumah Sakit. Penelitian yang bersifat deskriptif analitis ini dilakukan di RSUD Jombang, dengan menggunakan data primer dan data sekunder. Data primer dikumpulkan melalui wawancara dengan para narasumber yang terkait dengan menggunakan kuisioner sebagai alat pengumpulan datanya. Selanjutnya, data sekunder dikumpulkan dengan metode studi kepustakaan/studi dokumen. Dokumen yang diteliti adalah dokumen rekam medis dari enam pasien yang terlibat dalam sengketa medis yang diteliti. Data yang telah terkumpul dianalisis secara kualitatif.

Hasil penelitian menggambarkan bahwa upaya penyelesaian sengketa medis yang dilakukan di RSUD Jombang selama tahun 2008 sampai dengan awal tahun 2011 masih belum melembaga. Dikatakan demikian, sebab penyelesaian sengketa dilakukan secara segmental, tergantung bagian staf medis fungsional mana yang terlibat sengketa, diselesaikan oleh Bagian Humas RSUD Jombang, ada juga sengketa medis yang diselesaikan dengan membentuk Panitia Kecil secara ad hoc, bahkan ada yang diselesaikan langsung oleh Direktur RSUD Jombang, dan ada pula yang diselesaikan oleh dokter yang bersangkutan atas inisiastif sendiri. Model penyelesaian sengketa yang tidak melembaga dan tidak terstruktur sebagaimana terjadi di RSUD Jombang selama tahun 2008 sampai dengan awal tahun 2011, meskipun dari enam sengketa medis yang terjadi tidak ada satupun yang harus diselesaikan melalui jalur litigasi (pengadilan), namun demikian mengandung kelemahan-kelemahan, antara lain penyelesaiannya merugikan pihak ketiga yang berkepentingan karena dalam proses penyelesaiannya tidak secara penuh melibatkan pihak ketiga tersebut, penyelesaiannya dilakukan oleh organ Rumah Sakit yang kurang memahami hukum kesehatan sehingga persoalannya menjadi semakin rumit. Oleh karena itu pada rumah sakit perlu segera dibentuk komite yang bersifat tetap/melembaga yang bertugas menangani penyelesaian sengketa medis, yaitu dengan membentuk Komite Etik dan Hukum. Pembentukan Komite Etik dan Hukum tersebut sekaligus untuk melaksanakan ketentuan Pasal 19 ayat (2) Permenkes RI No 1045/MENKES/PER/XI/2006 tentang Pedoman Organisasi Rumah Sakit di Lingkungan Departemen Kesehatan.
\end{abstract}

Key word: Sengketa Medis, Malpraktik, Komite Etik dan Hukum 


\section{A. PENDAHULUAN}

Dalam beberapa tahun terakhir ini sering diberitakan di media massa seorang dokter atau tenaga kesehatan dituntut ganti rugi oleh pasien akibat kesalahan atau kelalaiannya dalam menjalankan tugas profesinya atau hasil pengobatan yang tidak sesuai dengan harapan pasien. Hal ini menunjukkan bahwa telah terjadi perubahan hubungan dokter dan pasien dari pola paternalistik menjadi pola konsumerisme-komersialisme ${ }^{1}$.

Pada pola hubungan paternalistik pasien mempercayakan kesembuhan penyakitnya kepada dokter. Dalam hal ini tampak bahwa kedudukan dan posisi dokter dan pasien tidak seimbang. Dokter memiliki kemampuan keilmuan dibidang kedokteran, sedang pasien adalah orang awam yang tidak tahu tentang penyakit,apalagi cara mengobatinya, sehingga pasien pasrah bagaimana dokter melakukan penyembuhan terhadap penyakitnya.

Sedang pada pola konsumerisme-komersialisme hubungan dokter dan pasien diidentifikasikan sebagai hubungan antara dokter sebagai penyedia jasa dan pasien sebagai penerima jasa pelayanan kesehatan. Pola ini menempatkan pasien pada posisi the patient knows best (pasien lebih tahu apa yang terbaik bagi dirinya daripada dokter). Semua tindakan kedokteran yang akan dilakukan harus mendapat persetujuan pasien sebagai implementasi dari hak otonomi pasien.

Perubahan posisi dalam hubungan dokter-pasien berkaitan dengan peningkatan taraf pendidikan, sosial-ekonomi, kemajuan ilmu pengetahuan dan teknologi, pengaruh media massa dan alat-alat komunikasi tampaknya ikut berperan dalam perubahan tersebut. Pasien menjadi lebih kritis dan peningkatan kesadaran hukum masyarakat membuat mereka mulai menyadari hak-haknya dan menuntut dokter untuk melaksanakan kewajibannya.

Hubungan dokter dan pasien tidak lagi dilihat sebagai hubungan kepercayaan semata, akan tetapi dengan meningkatnya pemahaman masyarakat akan hukum memandang hubungan pasien dengan dokter adalah hubungan hukum. Menurut hukum hubungan dokter dan pasien merupakan suatu perjanjian yang dikenal sebagai transaksi terapeutik.

Transaksi terapeutik adalah perjanjian antara dokter dengan pasien berupa hubungan hukum yang melahirkan hak dan kewajiban bagi kedua belah pihak. ${ }^{2}$ Objek dari perjanjian ini berupa upaya yang tepat untuk kesembuhan pasien bukan menjamin kesembuhan pasien. Dalam hukum perikatan perjanjian antara dokter dengan pasien termasuk pada perjanjian inspanings verbintenis atau perikatan upaya, sebab dalam konsep ini dokter hanya berkewajiban melakukan pelayanan kesehatan dengan penuh kesungguhan sesuai kemampuan dan kewenangannya, sesuai dengan standar profesi, standar medis serta standar prosedur operasional.

Perjanjian/kontrak terapeutik antara dokter-pasien, rumah sakit-pasien, rumah sakitdokter adalah hubungan antara subyek hukum dengan subyek hukum yang diatur oleh kaidahkaidah Hukum Perdata. Kaidah-kaidah hukum perdata mengatur pelaksanaan hak dan kewajiban timbal balik, dimana hak pasien menjadi kewajiban dokter dan hak dokter menjadi kewajiban pasien. ${ }^{3}$ Jika seorang pasien atau keluarganya menganggap bahwa dokter tidak melakukan kewajiban-kewajiban kontraktualnya, pasien dapat menggugat dengan alasan wanprestasi. Pasien juga dapat menuntut kompensasi secara materiil dan immateriil atas kerugian yang dideritanya.

1 Bambang Purnomo pada Nusye KI Jayanti, Penyelesaian Hukum dalam Malapraktik Kedokteran (Yogyakarta, Pustaka Yustisia, 2009), hal 4.

2 Bahder Johan Nasution, Hukum Kesehatan Pertanggungjawaban Dokter,(Jakarta, Rineka Cipta,2005) hal 11

3 Wila Chandrawila Supriadi, Hukum Kedokteran, (Bandung, Mandar Maju, 2001) hal 8 
Melihat ketentuan tersebut seyogyanya sebelum melakukan tindakan medis, pasien dan salah satu perwakilan keluarga sebagai saksi diberi informasi terlebih dahulu mengenai kondisi pasien, diagnosa penyakit, alternatif pengobatan, kekurangan dan kelebihan dari masing-masing pengobatan, dampak maupun kemungkinan resiko yang akan terjadi, hasil yang akan dicapai serta biaya yang harus dikeluarkan supaya pasien dapat memilih apa yang terbaik bagi dirinya, kemudian ditindak lanjuti dengan penandatanganan informed consent kalau memang pasien setuju.

Sengketa medis biasanya terjadi pada komunikasi yang kurang efektif antara dokterpasien atau terjadinya miskomunikasi antara tenaga kesehatan lain dengan pasien, sehingga pasien atau keluarganya merasa dirugikan atas tindakan medis tersebut. Kondisi seperti ini biasanya dilatar belakangi oleh ketidak puasan pasien sebelumnya terhadap pelayanan kesehatan yang telah diberikan oleh Rumah Sakit mungkin fasilitas, sarana, sikap dokter atau tenaga kesehatan yang bekerja disana. Atau pihak rumah sakit tidak segera merespon keluhan pasien, maka beda pendapat (sengketa medis) akan berkelanjutan. Bisa jadi pasien dan keluarga menyampaikan kasus tersebut ke media masa atau melaporkan ke Kepolisian serta Pengadilan.

Kesalahan persepsi hukum kesehatan yang bersumber dari kodifikasi hukum perdata atau pidana mengakibatkan pelecehan hukum kesehatan dan profesi kesehatan yang dapat dapat membahayakan pembangunan bidang kesehatan di Indonesia serta merugikan masyarakat sendiri.

Persoalan hukum yang muncul dalam transaksi terapeutik tidak serta-merta ditarik dalam wilayah hukum pidana atau perdata ${ }^{4}$, namun terlebih dahulu diselesaian dalam kompetensi peradilan profesi kesehatan, sehingga dapat diketahui dan diurai apakah persoalannya merupakan sengketa medis yang ditangani secara khusus (lex spesialis) atau di dalamnya terdapat persoalan hukum perdata atau pidana yang ditangani oleh peradilan umum.

Dengan diberlakukannya Undang-Undang No 36 Tahun 2009 tentang Kesehatan yang selanjutnya disebut Undang Undang Kesehatan khususnya pada Pasal 29 menyatakan bahwa "dalam hal tenaga kesehatan diduga melakukan kelalaian dalam menjalankan profesinya, kelalaian tersebut harus diselesaikan terlebih dahulu melalui mediasi". Artinya bila timbul sengketa medis antara tenaga kesehatan dengan pasien sebagai penerima jasa pelayanan kesehatan harus dilakukan mediasi terlebih dahulu sebelum kasus tersebut ke pengadilan.

Menurut observasi penulis sengketa medis di RSUD Jombang akihr-akhir ini mulai meningkat dan penyelesaiannya kebanyakan masih segmental tergantung staf medik fungsional mana yang bermasalah, sehingga penyelesaian sengketa medis kurang efektif dan efisien.

Bila di rumah sakit Jombang terdapat Komite Etik dan Hukum sebagaimana Peraturan Menteri Kesehatan Republik Indonesia Nomor 1045/ Menkes / Per/XI/2006 Tentang Pedoman Organisasi Rumah Sakit di Lingkungan Departemen Kesehatan Pasal 19 ayat :

(1) Komite adalah wadah non stuktural yang terdiri dari tenaga ahli atau profesi dibentuk untuk memberikan pertimbangan strategis kepada pimpinan rumah sakit dalam rangka peningkatan dan pengembangan pelayanan rumah sakit.

(2) Pembentukan komite ditetapkan oleh pimpinan rumah sakit sesuai kebutuhan rumah sakit, sekurang-kurangnya terdiri dari Komite Medik serta Komite Etik dan Hukum,

maka semua sengketa yang timbul akibat pelayanan kesehatan yang mengecewakan pasien termasuk sengketa medis akan ditindak lanjuti oleh Komite Etik dan Hukum Rumah Sakik sesuai dengan apa yang diamanahkan Pasal 29 Undang Undang Kesehatan sebagaimana disebutkan diatas.

\footnotetext{
${ }^{4}$ Nusye KI Jayanti, Penyelesaian Hukum dalam Malapraktik Kedokteran,(Yogyakarta,Pustaka Yustisia,2009) hal 7
} 
Selain itu penyelesaian sengketa medis di rumah sakit menjadi tanggung jawab rumah sakit sebagaimana diatur dalam Pasal 46 Undang Undang Rumah Sakit No 44 Tahun 2009 yang berbunyi "Rumah Sakit bertanggung jawab secara hukum terhadap semua kerugian yang ditimbulkan atas kelalaian yang dilakukan oleh tenaga kesehatan di Rumah Sakit."

\section{B. PERUMUSAN MASALAH}

Melihat latar belakang sebagaimana diuraikan diatas, maka usulan penelitian ini merumuskan beberapa permasalahan sebagai berikut :

1. Bagaimana penyelesaian sengketa medis di RSUD Jombang?

2. Apa urgensi pembentukan Komite Etik dan Hukum di Rumah Sakit?

\section{TUJUAN PENELITIAN}

Tujuan penelitian ialah pernyataan mengenai apa yang hendak dicapai. Berdasar latar belakang dan perumusan masalah, maka dapat dikemukakan bahwa tujuan penelitian sebagai berikut :

Tujuan umum :

Untuk mengetahui dan memahami urgensi pembentukan Komite Etik dan Hukum di Rumah Sakit dalam penyelesaian sengketa medis secara non litigasi.

Tujuan khusus :

1. Mengetahui bagaimana penyelesaian sengketa medis di RSUD Jombang.

2. Mengetahui dan memahami apa urgensi pembentukan Komite Etik dan Hukum di rumah sakit.

\section{MANFAAT PENELITIAN}

Penelitian ini diharapkan dapat memberi manfaat baik dari segi teoritis maupun dari segi praktis.

Manfaat dari segi teoritis :

1. Memberi sumbangan pemikiran tentang bagaimana penyelesaian sengketa medis di rumah sakit.

2. Memberi masukan tentang urgensi pembentukan Komite Etik dan Hukum di rumah sakit.

Manfaat dari segi praktis :

1. Manfaat praktis bagi manajemen rumah sakit, bahwa adanya Komite Etik dan Hukum Rumah Sakit dapat membantu tugas manajemen untuk menyelesaikan sengketa medis yang terjadi di rumah sakit serta menyusun kebijakan masalah etik dan hukum rumah sakit

2. Bagi dokter sebagai pemberi layanan kesehatan adanya Komite Etik dan Hukum di rumah sakit memberikan perasaan nyaman, karena adanya komite yang mendampingi, menjembatani dan mengusahakan saling pengertian antara dokter sebagai pemberi layanan kesehatan dan pasien/keluarga sebagai pihak yang menerima layanan kesehatan terhadap kasus yang disengketakan.

3. Bagi dokter dan tenaga kesehatan lain adanya Komite Etik dan Hukum di rumah sakit dapat berfungsi sebagai konsultan yang memberikan pembinaan dan pendidikan etik dan hukum yang terkait dalam transaksi terapeutik. 


\section{E. METODE PENELITIAN}

Metode ialah suatu prosedur atau cara untuk mengetahui sesuatu, yang mempunyai langkah-langkah sistematis. Sedangkan metodologi ialah suatu pengkajian dalam mempelajari peraturan-peraturan suatu metode. Jadi metodologi penelitian ialah suatu pengkajian dalam mempelajari kaedah- kaedah yang terdapat dalam penelitian. Ditinjau dari sudut filsafat, metodologi penelitian merupakan epistemologi penelitian. ${ }^{5}$

Pada penelitian ini penulis menggunakan metode kualitatif dengan pendekatan yuridis sosiologis artinya pengkajian terhadap masalah yang diteliti melalui observasi, wawancara, pemikiran dan telaah reflektif terhadap sifat/karakteristik khusus hukum positif (berdasarkan peraturan perundang-undangan yang berlaku) baik umum maupun khusus.

Dalam pembahasan metode penelitian selanjutnya akan diketengahkan sub bahasan metode pendekatan, spesifikasi penelitian, definisi operasional, jenis data, metode pengumpulan data serta metode analisis data.

\section{F. PEMBAHASAN}

\section{Penyelesaian sengketa medis di RSUD Jombang}

Pada tahun 2008 sampai dengan awal tahun 2011 penulis menemukan 6 sengketa medis yang terjadi di RSUD Jombang. Adapun penyelesaian sengketa medis di RSUD Jombang sebagaimana diketahui dari penelitian 6 kasus tersebut dilakukan secara segmental tergantung bagian staf medis fungsional mana yang bersengketa. Karena tidak ada lembaga yang dibentuk untuk menyelesaikan sengketa medis, maka yang menyelesaikannya berbedabeda, antara lain:

a. Diselesaikan oleh bagian keuangan ;

b. Diselesaikan oleh dokter/tenaga kesehatan lain yang bersengketa;

c. Diselesaikan langsung oleh manajemen/Direktur ;

d. Diselesaikan oleh Humas berkolaborasi dengan Komite Medik; atau

e. Dengan membentuk Panitia Kecil secara ad hoc.

Model penyelesaian sengketa medis sebagaimana diuraikan diatas membutuhkan waktu lama dan hasilnyapun kurang efektif serta efisien. Keputusan yang diambil juga bervariasi tergantung kepada siapa yang memutuskan dan pemahaman terhadap Hukum Kedokteran yang mendasari transaksi terapeutik.

Menurut hukum kedokteran, hubungan tenaga kesehatan (dokter) dan pasien merupakan suatu perjanjian yang obyeknya berupa pelayanan medis atau upaya penyembuhan yang dikenal sebagai transaksi terapeutik. Perikatan yang timbul dari transaksi terapeutik disebut inspanning verbintenis yaitu perikatan ikhtiar bukan perikatan hasil. Akibat perikatan tersebut kedua belah pihak mempunyai hak dan kewajiban masing masing. Pelaksanaan kewajiban tenaga kesehatan (dokter) menjadi hak pasien, sebaliknya kewajiban pasien menjadi hak dokter. ${ }^{6}$

Bagi pihak dokter, prestasi dalam melakukan sesuatu merupakan kewajiban hukum untuk berbuat sebaik dan semaksimal mungkin melaksanakan perawatan medis bagi kepentingan kesehatan pasien. Kewajiban hukum bagi dokter untuk tidak berbuat salah atau keliru dalam perlakuan medis, artinya kewajiban untuk melakukan pelayanan kesehatan kepada pasien dengan sebaik-baiknya sesuai standar profesi maupun standar medis yang sudah ditetapkan sebagaimana diatur oleh Undang Undang Praktik Kedokteran No. 29 Tahun 2004 Pasal 51 huruf

\footnotetext{
${ }^{5}$ Husaini Usman, Purnomo Setiady Akbar, Metodologi Penelitian Sosial, (Jakarta, Bumi Aksara,Tahun 2000) hal 42

${ }^{6}$ Wila Chandrawila Supriadi, op.cit, hal 8
} 
(a) yang berbunyi: "Dokter atau dokter gigi dalam melaksanakan praktik kedokteran mempunyai kewajiban a. Memberikan pelayanan medis sesuai dengan standar profesi dan standar prosedur operasional serta kebutuhan medis pasien".

Menurut Leenen dan Van der Mijn ahli hukum kesehatan Belanda berpendapat bahwa dalam melaksanakan profesinya, seorang tenaga kesehatan (dokter) perlu berpegang pada tiga ukuran umum, yaitu:?

a. Kewenangan;

b. Kemampuan rata-rata; dan

c. Ketelitian yang umum.

Dari 6 kasus yang diteliti dapat diketahui bahwa penyebab sengketa medis yang paling banyak adalah komunikasi antara tenaga kesehatan dengan pasien/keluarga yang kurang baik, kurang efektif sebagaimana diatur oleh Undang-undang Praktik Kedokteran No. 29 Tahun 2004 Pasal 52 huruf a bahwa pasien dalam menerima pelayanan pada praktik kedokteran, mempunyai hak mendapat penjelasan secara lengkap tentang tindakan medis sebagaimana dimaksud dalam Pasal 45 ayat (3) yaitu diagnosa dan tata cara tindakan medis, tujuan tindakan medis yang dilakukan, alternatif tindakan lain dan risikonya, risiko dan komplikasi yang mungkin terjadi serta prognosis terhadap tindakan yang dilakukan.

Komunikasi yang dimaksud tidak hanya terbatas pada pemberian informasi oleh dokter kepada pasien/keluarga mengenai kesehatan pasien, pengobatan atau tindakan yang akan dilakukan, alternatif tindakan, keuntungan dan kerugian masing-masing tindakan agar pasien/keluarga dapat memilih serta memberikan persetujuan terhadap tindakan yang dipilih. Namun keluhan pasien terhadap sarana, fasilitas kesehatan yang diterima atau sikap tenaga kesehatan yang kurang simpatik harus segera direspon dengan baik agar tidak menimbulkan rasa tidak puas pasien maupun keluarga terhadap pelayanan yang diterima.

Ketidak pahaman petugas maupun RS terhadap kebutuhan dan keinginan pasien akan mempengaruhi kepuasan pasien. Pasien yang tidak puas terhadap fasilitas atau pelayanan kesehatan yang diberikan pasti komplain dan bila komplain pasien tidak segera ditanggapi akan berdampak pada ketidak puasan dalam menerima pelayanan kesehatan yang akhirnya dapat berubah menjadi sengketa medis.

Selain faktor komunikasi yang kurang efektif sebagai penyebab sengketa medis terdapat juga beberapa faktor lain yang mendukung terjadinya sengketa medis antara lain :
a. ketidakjelasan siapa yang harus merespon keluhan;
b. ketidaksamaan persepsi tentang malpraktik;
c. adanya pihak ketiga;
d. tuntutan ganti rugi;
e. lambannya responsibilitas RS terhadap keluhan pasien;
f. ketidak pahaman hak dan kewajiban pasien maupun tenaga kesehatan;
g. tuntutan pasien terlalu tinggi.

Faktor-faktor penyebab sengketa medis ternyata lebih banyak faktor non medis bukan kelalaian atau pelanggaran terhadap standar medis maupun standar prosedur operasional sebagaimana diatur oleh Undang-undang Praktik Kedokteran No. 29 Tahun 2004 Pasal 50 huruf b menentukan bahwa dokter dalam melaksanakan praktik kedokteran mempunyai hak memberikan pelayanan medis menurut standar profesi dan standar prosedur operasional". Sedang kewajiban dokter dalam melaksanakan praktik kedokteran diatur dalam Pasal 51 huruf a

\footnotetext{
${ }^{7}$ Adami Chazawi, Malpraktik Kedokteran Tinjauan Norma dan Doktrin Hukum, ( Malang Bayumedia Publishing, , Maret 2007) hal 29-31
} 
yaitu memberikan pelayanan medis sesuai dengan standar profesi dan standar prosedur operasional serta kebutuhan medis pasien. Selanjutnya, Pasal 52 huruf c menentukan bahwa pasien berhak mendapatkan pelayanan sesuai dengan kebutuhan medis.

Penyelesaian sengketa medis antara dokter dan pasien melalui jalur hukum menjadi masalah yang dilematis. Pilihan penyelesaian semacam ini memperoleh reaksi keras dari kalangan profesi medis, karena mereka khawatir mengancam otonomi profesi medis. Oleh karena itu perlu diatur penyelesaian sengketa medis yang lebih bermartabat. ${ }^{8}$

\section{Urgensi Pembentukan Komite Etik dan Hukum di Rumah Sakit}

Adanya 6 kasus sengketa medis di rumah sakit Jombang selama kurun waktu 2 tahun (tahun 2008 - awal tahun 2011) menunjukkan bahwa terjadi pergeseran pendapat lama tentang "doctor know best" ke arah kesetaraan dan autonomi. Hubungan yang terjadi antara dokterpasien telah berubah dari pola paternalistik menjadi pola konsumerisme-komersialisme. Pada pola konsumerisme-komersialisme hubungan dokter dan pasien diidentifikasikan sebagai hubungan antara dokter sebagai penyedia jasa dan pasien sebagai penerima jasa pelayanan kesehatan. Pola ini menempatkan pasien pada posisi the patient knows best (pasien lebih tahu apa yang terbaik bagi dirinya daripada dokter).

Hal ini menunjukkan telah terjadi peningkatan pemahaman masyarakat tentang hukum dan masyarakat mulai sadar akan haknya dalam mendapatkan pelayanan kesehatan yang profesional serta berupaya melindungi dirinya dari pihak lain yang merugikan.

Hasil penelitian di RSUD Jombang menunjukkan bahwa tenaga kesehatan di RSUD Jombang masih kurang memahami hukum, khususnya hukum kesehatan, sedangkan pasien maupun masyarakat sudah mulai paham akan hukum namun tidak paham hukum kesehatan yang bersifat sui generis. Akibatnya bila ada hasil pengobatan atau tindakan kedokteran yang tidak sesuai dengan harapan dan keinginan pasien mereka menganggap dokter dan/atau tenaga kesehatan telah melakukan malpraktik, sehingga mereka tidak segan-segan menuntut bahkan membawa pengacara untuk melakukan tuntutan ke rumah sakit. Pada pihak yang lain, upaya penanganan dan penyelesaian sengketa medis yang dilakukan di RSUD Jombang pada tahun 2008 sampai dengan awal tahun 2011 menunjukkan model penyelesaian sengketa yang belum konsisten dan terpadu (melembaga), yaitu dengan model penyelesaian secara segmental.

Model Penyelesaian sengketa medis yang dilakukan di RSUD Jombang sebagaimana disebutkan di atas, meskipun dilakukan secara kooperatif dan dimaksudkan untuk menghasilkan kesepakatan yang win-win solution, namun masih terdapat beberapa kelemahan atau kekurangan, antara lain:

a. Kesepakatannya merugikan pihak ketiga. Hal ini terjadi karena kurangnya pemahaman petugas yang menangani penyelesaian sengketa tentang hukum kesehatan, khususnya hubungan hukum dan tanggungjawab hukum.

b. Kurang menjamin efisiensi dan efektivitas penyelesaian sengketa yang dapat berakibat persoalan menjadi semakin rumit, karena belum ada kepastian institusi/komite yang betugas dan bertanggungjawab dalam merespon keluhan pelayanan kesehatan yang diberikan oleh RSUD Jombang yang datang dari pasien, keluarga pasien, masyarakat maupun instansi pemerintahan terkait.

c. Mempengaruhi konsentrasi dan produktivitas tenaga kesehatan, karena harus mengambil inisiatif dan melakukan penyelesaian sendiri sengketa medis Disatu pihak dokter mempunyai

\footnotetext{
${ }^{8}$ Marcel Ana, Anna Maria Wahyu Setyowati, Dilema Etika dan Hukum Dalam Pelayanan Medis, (Bandung, Mandar Maju, 2010) hal 19
} 
waktu terbatas, karena harus memberikan pelayanan kepada pasien yang lain. Hal ini jelas akan mengganggu kinerja dokter.Terlambatnya responsibilitas terhadap keluhan pasien/keluarga, karena ketidak jelasan siapa yang menangani komplain dapat berakibat terjadinya sengketa medis.

d. Ketidakpahaman tenaga kesehatan, pasien/keluarga dan masyarakat terhadap aspek etik, moral dan hukum dalam pelayanan kesehatan serta ketidaksamaan persepsi tentang malpraktik menyebabkan meningkatnya tuntutan kasus dugaan malpraktik bila hasil pelayanan yang diberikan tenaga medis/ tenaga kesehatan di RS tidak sesuai yang diharapkan.

e. Tidak adanya komite yang menangani keluhan pasien menyebabkan tidak terdokumentasinya semua keluhan pasien atau sengketa medis yang terjadi di RSUD Jombang. Hal ini menyebabkan RS kehilangan data sebagai bahan evaluasi pelayanan yang dilakukan tenaga kesehatan di RS akibatnya tidak dapat membuat rencana tindak lanjut sebagai upaya meminimalisir keluhan pasien atau untuk meningkatkan kualitas pelayanan.

f. Tidak adanya komite yang dapat memberikan pembinaan dan pendidikan etik dan hukum dalam pelayanan kesehatan dapat menyebabkan tenaga kesehatan di RS kurang memperhatikan etika dalam menjalankan profesi dan tidak memahami tanggung jawab hukum terhadap pelanggaran, hak dan kewajiban tenaga kesehatan, RS serta pasien. Hal ini akan merugikan RS apalagi setelah diberlakukannya Undang Undang Rumah Sakit No 44 Tahun 2009 sejak tanggal 28 Oktober 2009.

Kelemahan-kelemahan model penyelesaian sengketa yang dipraktikkan di RSUD Jombang sebagaimana disebutkan di atas apabila tidak segera dievaluasi dan ditindaklanjuti dengan membentuk komite penyelesaian sengketa yang tetap, dalam menghadapi sengketa medis yang mungkin timbul pada masa-masa yang akan datang, maka akan banyak menguras tenaga pikiran, dan anggaran bahkan tidak menutup kemungkinan penyelesaian sengketa berlanjut ke pengadilan (jalur litigasi). Sebagaimana diketahui penyelesaian secara litigasi membutuhkan waktu lama, mengganggu pekerjaan dan belum tentu dapat diselesaikan secara win-win solution. Jika hal ini sampai terjadi berarti penyelesaian sengketa medis yang ada di RSUD Jombang tidak sesuai dengan apa yang diamanahkan oleh Pasal 29 Undang Undang Kesehatan No 36 Tahun 2009 yang berbunyi: "Dalam hal tenaga kesehatan diduga melakukan kelalaian dalam menjalankan profesinya, kelalaian tersebut harus diselesaikan terlebih dahulu melalui mediasi".

Pasal 46 Undang Undang Rumah Sakit No 44 Tahun 2009, yang berbunyi: "Rumah Sakit bertanggung jawab secara hukum terhadap semua kerugian yang ditimbulkan atas kelalaian yang dilakukan oleh tenaga kesehatan di Rumah Sakit", dan Pasal 29 ayat (1) huruf s yang menyatakan bahwa Rumah Sakit mempunyai kewajiban "melindungi dan memberikan bantuan hukum bagi semua petugas Rumah Sakit dalam melaksanakan tugas".

Melihat penyelesaian sengketa medis yang dilakukan oleh panitia kecil lebih efektif dan efisien, guna menunjang pengelolaan klinik yang baik dan meminimalisir kasus sengketa medis di rumah sakit, serta mengingat bahwa dalam transaksi terapeutik tidak hanya berkaitan dengan aspek medik, tetapi juga terdapat aspek moral, etik dan aspek hukum, maka di RSUD Jombang perlu segera dibentuk Komite Etik dan Hukum di Rumah Sakit oleh direktur sebagaimana diamanahkan oleh Pasal 19 ayat (2) Permenkes RI No 1045/MENKES/PER/XI/2006 tentang Pedoman Organisasi Rumah Sakit di Lingkungan Departemen Kesehatan yang dalam pelaksanaannya dapat berkolaborasi dengan subkomite mutu dan subkomite etika dan disiplin profesi.

Tujuan dibentuknya Komite Etik dan Hukum di Rumah Sakit adalah membantu Direktur Rumah Sakit dalam bidang pembinaan dan pendidikan tenaga kesehatan yang berkaitan dengan 
etika dan hukum dalam pelayanan kesehatan, melindungi hak dan kewajiban dokter-pasien, membahas kasus etikomedikolegal, segera merespon pengaduan dan menindak lanjuti sengketa medis yang terjadi di rumah sakit serta membantu Direktur dalam menyusun kebijakan terkait Etika dan Hukum di Rumah Sakit.

Manfaat dibentuknya Komite Etik dan Hukum Rumah Sakit antara lain:

1. Mencegah dan meminimalisir terjadinya kasus etikomedikolegal di Rumah Sakit dengan melakukan pendidikan etika, disiplin profesi dan hukum dalam pelayanan kesehatan;

2. Mengkaji kasus etikomedikolegal yang terjadi di RSUD Jombang maupun yang terjadi di Rumah Sakit lain atau issu yang berkembang di mass media;

3. Segera merespon keluhan pasien, tenaga kesehatan lain terkait dengan pelaksanaan pelayanan kesehatan yang dilakukan di RSUD Jombang agar tidak menimbulkan sengketa medis;

4. Mengupayakan penyelesaian kasus sengketa medik melalui jalur non litigasi; dan

5. Menyusun kebijakan terkait dengan etika, disiplin profesi dan hukum dalam pelayanan kesehatan di RSUD Jombang.

Upaya-upaya yang dapat dilakukan oleh Komite Etik dan Hukum Rumah Sakit dalam meningkatkan responsibilitas keluhan pasien atau tenaga kesehatan lain dan penyelesaian kasus sengketa medis adalah sebagai berikut:

a. Membuat alur pelayanan keluhan dari seluruh unsur pelayanan kesehatan yang ada di rumah sakit seperti, rawat jalan, rawat inap, unit gawat darurat, pemeriksaan penunjang, dengan menegaskan bahwa semua keluhan diterima di sekretariat Komite Etik dan Hukum;

b. Menindak lanjuti keluhan atau tuntutan pasien dengan mengadakan pertemuan antara tim Komite Etik dan Hukum dengan unit terkait yang bermasalah;

c. Mengadakan pertemuan dengan keluarga pasien untuk merespon dan memahami objek yang menjadi sengketa.

d. Melaksanakan klarifikasi kasus dan melihat bukti rekam medik apakah ada pelanggaran terhadap obyek yang dijanjikan, adakah pelanggaran terhadap kepatuhan pelaksanaan standar profesi, standar prosedur operasional. Hal ini dilakukan untuk melihat adakah wanprestasi atau perbuatan melanggar hukum sebagaimana yang dituduhkan pasien, karena dari sudut hukum kelalaian/kesalahan yang diperbuat seorang dokter meliputi beberapa aspek hukum, yaitu aspek hukum pidana, hukum perdata dan hukum administrasi negara. Ketiga aspek saling berkaitan satu sama lain. Mengadakan pertemuan antara keluarga pasien, dokter/ tenaga kesehatan yang bermasalah dengan Komite Etik dan Hukum untuk mencari titik temu permasalahan serta melakukan negosiasi dalam penyelesaian masalah. Apabila tercapai kesepakatan perdamaian, maka hasil kesepakatan ditulis dan ditandatangani oleh kedua belah pihak yang bersengketa, serta Komite Etik dan Hukum.

e. Apabila dalam proses negosiasi tidak berhasil mencapai kesepakatan perdamaian, maka ditawarkan untuk menempuh proses mediasi dengan menunjuk seorang mediator yang disepakati oleh kedua belah pihak yang bersengketa. Apabila dalam proses mediasi terjadi kesepakatan, maka hasil kesepakatan ditulis dan ditandatangani oleh kedua belah pihak yang bersengketa, serta mediator kemudian didaftarkan ke pengadilan sebagai akta otentik. 
Bila di RSUD Jombang sudah ada Komite Etik dan Hukum Rumah Sakit, maka alur penanganan sengketa medis yang disarankan sebagai berikut:

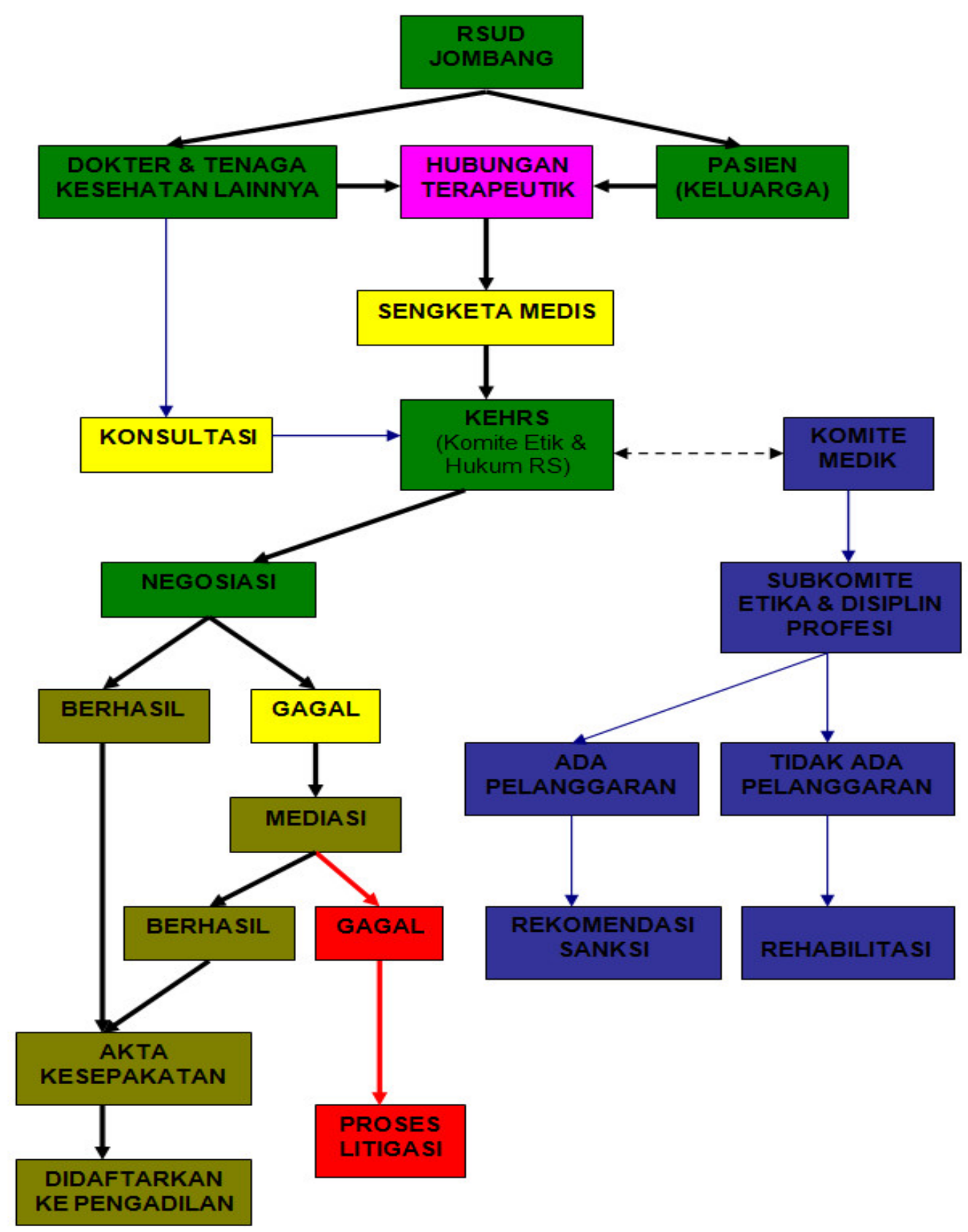

Gambar 1: Alur Penanganan Sengketa Medis oleh KEHRS 


\section{G. PENUTUP}

\section{Kesimpulan}

Dalam penelitian ini terdapat dua permasalahan, yaitu "Bagaimana penyelesaian sengketa medis di RSUD Jombang”, dan “Apa urgensi pembentukan Komite Etik dan Hukum di RSUD Jombang". Berdasarkan hasil penelitian dan pembahasan sebagaimana diuraikan dalam Bab III, dapat diambil kesimpulan sebagai berikut:

1. Penyelesaian sengketa medis di RSUD Jombang selama ini diselesaikan secara segmental di masing-masing ruangan atau bagian mana yang bersengketa, sehingga penyelesaiannya kurang efektif dan efisien.

2. Adanya perubahan pola transaksi terapeutik dari paternalistis ke pola konsumerisme komersialisme, meningkatnya kesadaran masyarakat memperoleh perlindungan hukum dalam mendapatkan pelayanan kesehatan menyebabkan semakin meningkatnya tuntutan hukum kepada Dokter dalam menjalankan tugas profesinya.

3. Adanya Undang Undang Praktik Kedokteran No 29 Tahun 2004, Undang Undang Kesehatan No 36 Tahun 2009, Undang Undang Rumah Sakit No 44 Tahun 2009 dan Permenkes RI No 1045/MENKES/PER/XI/2006 tentang Pedoman Organisasi Rumah Sakit di Lingkungan Departemen Kesehatan maka urgensi sekali dibentuknya Komite Etik dan Hukum Rumah Sakit sebagai badan yang resmi dibentuk berdasarkan Surat Keputusan Direktur Rumah Sakit Jombang untuk menindaklanjuti sengketa medis di RSUD Jombang. Dengan dibentuknya Komite Etik dan Hukum Rumah Sakit penyelesaian sengketa dugaan malpraktik di RSUD Jombang yang semula segmental akan ditangani secara sentral oleh Komite Etik dan Hukum Rumah Sakit secara non litigasi, sehingga penyelesaiannya menjadi lebih cepat dan tercapai win-win solution.

\section{Saran}

1. Segera diterbitkan Peraturan Menteri Kesehatan tentang Pedoman Pelaksanaan Komite Etik dan Hukum Rumah Sakit sebagai payung hukum dalam pelaksanaannya.

2. Semua rumah sakit perlu membentuk Komite Etik dan Hukum Rumah Sakit untuk menangani kasus etikomedikolegal yang mungkin terjadi dalam transaksi terapeutik.

3. Dalam membentuk Komite Etik dan Hukum Rumah Sakit harus ada seorang anggota yang kompeten dalam bidang hukum dan kesehatan atau minimal ahli hukum agar dapat menyelesaikan tugasnya secara profesional.

4. Mengkaji ulang alur penanganan sengketa medis di RS yang penulis gambarkan agar dapat dipakai diseluruh $\mathrm{RS}$ 


\section{DAFTAR PUSTAKA}

Abbas Syahrizal, Mediasi, (Jakarta: Fajar Interpradana Offset, cetakan pertama, 2009).

Chazawi Adami, Malpraktik Kedokteran,( Malang: Bayumedia Publishing, cetakan Pertama 2007).

Dewi D.S., Diktat kuliah Penyelesaian Sengketa Medis melalui Mediasi, (MHKes UNIKA Soegijapranata, Semarang, 2010).

Guwandi, Hukum Medik (Jakarta: penerbit FKUI cetakan ketiga, 2007).

Guwandi,Medical Error dan Hukum Medis,( Jakarta: penerbit FKUI cetakan kedua, 2007).

Guwandi , Dugaan Malpraktek Medik dan Draft RPD Perjanjian Terapeutik Antara Dokter dan Pasien,( Jakarta: penerbit FKUI, 2006).

Hadijanto Bantuk, Peran Komisi Etik Rumah Sakit (makalah seminar) "Kesadaran Bioetika dan Tanangan Hukum" di UNIKA Soegijapranata Semarang, 31 Oktober 2009.

Hadi Sutrisno, Metodologi Research, (Yogyakarta: Andi Offset, 1989).

Hanafiah M.Jusuf \& Amir Amri, Etika Kedokteran dan Hukum Kesehatan, ( Jakarta: Penerbit Buku Kedokteran EGC, 1999).

Isfandiarie Anny, Tanggung Jawab Hukum dan Sanksi bagi Dokter Buku I dan II,( Jakarta: , Prestasi Pustaka cetakan Pertama, 2006).

Jayanti Nusye KI, Penyelesaian Hukum dalam Malapraktik Kedokteran, (Jakarta: Pustaka Yustisia, cetakan pertama, 2009).

Komalawati D. Veronica, Hukum dan Etika Dalam Praktik Dokter, (Jakarta: Pustaka Sinar Harapan cetakan pertama, 1989).

Manik V.A. Binus, Penyelesaian Kasus Hukum di Rumah Sakit melalui jalur Litigasi dan Nonlitigasi,( Yogyakarta: makalah pelatihan Peningkatan Ketrampilan Medicolegal di Rumah Sakit, Mei 2010).

Nasution Baher Johan, Hukum Kesehatan Pertanggung Jawaban Dokter, (Jakarta: Rineka Cipta, 2005).

Notoatmojo Soekijo, Etika dan Hukum Kesehatan, (Jakarta: Rineka Cipta, 2010).

Seran Marcel,Anna Maria Wahyu Setyowati,Dilema Etika dan Hukum Dalam Pelayanan Medis, ( Bandung, Mandar Maju, 2010).

Soewono Hendrojono, Pertanggungjawaban Hukum Malpraktik Dokter dalam Transaksi Terapeutik,( Surabaya: Penerbit Srikandi cetakan pertama, 2007).

Supriadi Wila Chandrawila , Hukum Kedokteran,( Bandung: Mandar Maju, cetakan pertama, 2001).

Usman Husaini, Akbar Purnomo Setiady, Metodologi Penelitian Sosial,(Jakarta: PT Bumi Aksara cetakan ketiga, 2000) 
Peraturan Perundang-Undangan:

Kitab Undang-Undang Hukum Pidana

Kitab Undang-Undang Hukum Perdata

Undang-Undang No. 44 Tahun 2009 Tentang Rumah Sakit

Undang-Undang No. 36 Tahun 2009 Tentang Kesehatan

Undang-Undang No. 29/2004 Tentang Praktik Kedokteran

Undang-Undang No. 30/1999 Tentang Arbitrase dan Penyelesaian Sengketa Alternatif

Permenkes 755/MENKES/PER/IV/2011 Tentang Penyelenggaraan Komite Medik di RS.

Permenkes No 1045/MENKES/PER/XI/2006 Tentang Pedoman Organisasi RS di Lingkungan Depkes 